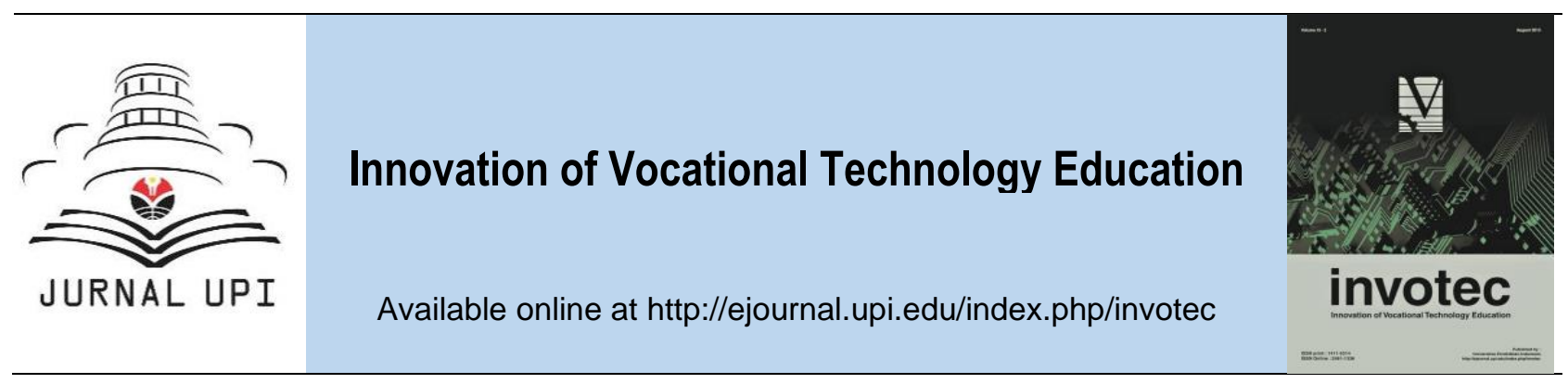

\title{
Engineering Cadres and Synergy Challenges in Nigeria: A Perspective
}

\author{
Adewuyi Philip Adesola
}

College of Engineering, Bells University of Technology, P. M. B. 1015, Ota, Ogun State, Nigeria

\section{ARTICLE INFO}

Article history:

Received: 11 April 2019

Received in revised form: 22 May 2019

Accepted: 25 August 2019

Available online: 31 August 2019

Keywords:

craftsmen;

dichotomy;

engineers;

artisans;

technologists;

technical;

vocational

Authors email:

paadewuyi@bellsuniversity.edu.ng

\section{A B S T R A C T}

Engineering family is such a scientific field that has to work as a unit without progress and development suffers in any society. Each engineering family cadre rests on the other to form a synergy upon which transformational strength is dependent as experienced in developed countries. However, in Nigeria there are myriads of challenges facing engineering profession, especially technical and vocational training institutions and their public acceptability, ranging from governmental to societal challenges thereby limiting its growth and development. In this work, the root challenges that confront engineering profession in terms of cadre structure imbalance are analyzed. The trend in terms of educational training mostly desired by individuals and the relative causes and effects are also reviewed. Overall, impact of these challenges on the society are x-rayed in terms of infrastructural and technological development, indigenous engineering professionals' availability, and cadre structure imbalance. Solutions as to ways of correcting these identified anomalies, in order to bring about healthy and functional relationship among engineering cadres in Nigeria for the general development of the country are suggested in this work.

\section{Introduction}

Engineering is defined as the profession in which the mathematical and natural sciences knowledge are gained either in a formal or informal situation which is used to develop objects that are economical, safe and durable for the overall improvement of standard of living (Pleasant \& Olson, 2018; Sheppard et al., 2006). The development of any society depends on the level of engineering and technological involvement of the society. Countries classified called developed countries and those that are developing have made conscious efforts to integrate the practice of engineering into their developmental programmes through the promotion and concerted implementation of Science, Technology, Engineering, and Mathematics education - STEM (Jayarajah, Saat, \& Rauf, 2014). However, the field of engineering has cadres which represents levels at which members of a particular cadre are expected to be involved in the practice of engineering in order to bring structure and orderliness to the engineering profession. In other words, cadre simply represents hierarchy that 
exists in the engineering profession. This cadre or structure or hierarchy is determined by the level of formal education attained by an engineering personnel, the level of professional experience as well as level of professional trainings acquired by an engineering personnel (Akinsanya \& Omotayo, 2013).

In engineering profession, upward movement from lower cadre to higher cadre is allowed provided the concerned engineering personnel has attained higher qualifications and satisfies the professional body's requirements. This is the synergy existing amongst engineering bodies in countries that are tagged developed such as; United States of America, United Kingdom, Germany, France, and the remaining twenty seven first world, high-income, industrial countries (Jose et al., 2018). This synergy ordinarily should bring robustness to the engineering profession by promoting harmonious relationship amongst engineering practitioners irrespective of cadre differences. Instead, the experiences in Nigeria particularly, rather than bringing harmonious relationship that would lead to development, are segregation, neglect of duties, egoism, sabotage of projects, neglect of technical and vocational education, and upsurge in the number of individual craving for university degree qualification by all means in order to called engineers. As could be drawn from the meaning of engineering, any knowledge gained that is not applied is as good as story- telling. It is therefore important to have engineering technology which is part of technological field that requires the application of scientific and engineering knowledge and methods combined with technical skills in support of engineering activities. This is what lies in the occupational spectrum between the craftsman and the engineer popularly referred to as engineering technologist. This is not to be in Nigerian context.

These problems have led to a drastic imbalance in the pyramid structure that should exist in a well-structured engineering practice as depicted in Figure 1. More craftsmen are needed followed by lesser technicians, then fewer technologists who would in turn be headed by fewer number of engineers (Smith, 1990). In Nigeria today, more people want to be engineers and fewer are satisfied belonging to other cadres. This is a serious problem that must be fixed through sensitization and reorientation of the Nigerian society by all engineering stakeholders, part of which this work tends to address. The remaining part of this work is divided into the following sections; structure of selected engineering bodies around the world, current structure of engineering bodies in Nigeria, the challenging trend, other factors responsible for cadre-structure imbalance, effect of cadre-structure imbalance, the way out as well as conclusion.

\section{Structure of Selected Engineering Bodies around the World}

As is the practice in developed countries and based on the United States and Japan engineering activities, a cadre of engineering body could not operate in isolation. According to National Academies in 1999, it is reported that beyond inter-cadre activities, engineering development requires cooperation among technical personnels cutting across different engineering 
fields, cultural background, language as well as nationalities (National Academies, 1999). In order to promote mutual cooperation beyond the level of engineering cadres, United Nations Educational, Scientific and Cultural Organization (UNESCO) progress report of 2012 shows a deliberate attempt made to foster cooperation among engineering bodies across the world through the signing of memorandum of understanding called UNESCO Engineering Initiative (UEI). This effort has brought about partnership with the African Network of Science and Technological Institutions (ANSTI), the American Society of Mechanical Engineers (ASME), the Institute of Electrical and Electronics Engineers (IEEE), the World Federation of Engineering Organizations (WFEO), Airbus and the Intel Foundations. The partnerships further aim at developing engineering education, encouraging women in engineering and promotion of interdisciplinary and sustainable engineering (UNESCO, 2012).

Notable engineering bodies across the world and recognized by UNESCO are; Academy of Engineering and Technology (ASEAN) that supports academies in Africa, Federation of African Engineering Organizations (FAEO) which works in partnership with the African Network of Scientific and Technological Institutions (ANSTI), World Federation of Engineering Organizations (WFEO), and UNESCO. As part of activities to encourage the development of engineering education and improve the public's understanding of engineering and technological sciences, International Council of Academies of Engineering and Technological Sciences was established whose membership cut across twenty six (26) countries. International Federation of Consulting Engineers (FIDIC) also has members from more than ninety (90) countries. Its activities aim at promoting the importance of engineering for socio-economic development and also supports youths in their quest for professional development. At international level, World Federation of Engineering Organizations (WFEO) was formed in 1968 under the sponsorship of UNESCO. About twenty million engineers from over ninety (90) countries are members. WFEO promotes engineering education and skills development especially through youth conferences. WFEO recently supports collaborative efforts for sustainable development (UNESCO, 2010).

All these collaborative efforts are further reinforced through successful organization of engineering work based on hierarchies. There must be a synergy among various engineering cadres to achieve great success in the professional practice of engineering as experienced in the history of engineering professional bodies even in developed countries (Meiksins \& Chris, 1993).

\subsection{Current structure of engineering bodies in Nigeria}

The current structure of engineering bodies in Nigeria comprises various engineering bodies established to accommodate different cadres of engineering professionals as identified groups whose activities are regulated by the Federal Government of Nigeria under the Council for the Regulation of Engineering in Nigeria (COREN). Their roles are as highlighted below: 


\subsubsection{The Nigerian Society of Engineers (NSE)}

The umbrella body for engineering profession in Nigeria is the Nigerian Society of Engineers. NSE was founded in 1958 as an avenue for the professional development of its members as well as technological development of the country. From its name, NSE is strictly for engineers who have acquired relevant engineering degrees and expertise or its equivalent qualifications. Any qualification short of this, automatically disqualifies the applicant. In order words, NSE is an elite society of engineers in the engineering family.

\subsubsection{The Nigeria Academy of Engineering (NAE)}

An important body in the affairs of engineering profession in Nigeria that prides itself as the 'Think Tank' for Engineering and Technology is the Nigeria Academy of Engineering. The academy was established in 1997 with membership spread across all disciplines in Engineering, mostly highly experienced engineers who have made their marks in their chosen fields. The Nigeria Academy of Engineering's role is majorly to promote excellence in the practice of engineering in Nigeria.

\subsubsection{The Nigerian Association of Technologists in Engineering (NATE)}

In 1988, Nigerian Association of Technologists in Engineering (NATE) was established with the aim of fostering the self-reliant technological development in Nigeria. NATE members are mainly holders of Higher National Diploma and National Diploma (ND) from Polytechnics and Colleges of Technology and holder of equivalent qualifications.

\subsubsection{The Nigerian Association of Engineering Craftsmen (NAEC)}

In fulfillment of one of its objectives of bringing engineering Craftsmen together, the Nigerian Association of Engineering Craftsmen was founded in 1993. The association caters for its members through seminars, trainings, conferences as well as lectures. Membership is mainly for holders of National Craft Certificates.

\subsubsection{The Nigerian Society of Engineering Technicians (NISET)}

The Nigerian Society of Engineering Technicians was established as a professional body to provide central administration for all Engineering Technicians in Nigeria in 1996 to give proper recognition to holders of National Diploma (ND).

\subsubsection{Council for The Regulation of Engineering in Nigeria (COREN)}

In order to unify and give due recognitions to all professional engineering societies and associations, the Council for the Regulation of Engineering in Nigeria (COREN) was established in 1970 by the government of the Federal Republic of Nigeria. The Council is empowered by relevant decrees to regulate and control the training and practice of engineering in Nigeria and enforce registration of all engineering personnel and consulting firms (COREN, 2019). 
It should be noted that COREN is the only body that is saddled with regulation of engineering practice that is strictly backed by law.

According to COREN, Engineering cadres in Nigeria are:

- Engineers

- Engineering Technologists

- Engineering Technicians

- Engineering Craftsmen

By hierarchy, engineers are highest in rank in the profession, followed by engineering technologists, engineering technicians, and engineering craftsmen in that order. Great management of inter-relationship among these cadres is highly essential to prevent professional rancor. This has not been the case in Nigeria as segregation due to lack of professional ethics adherence, is what is being experienced.

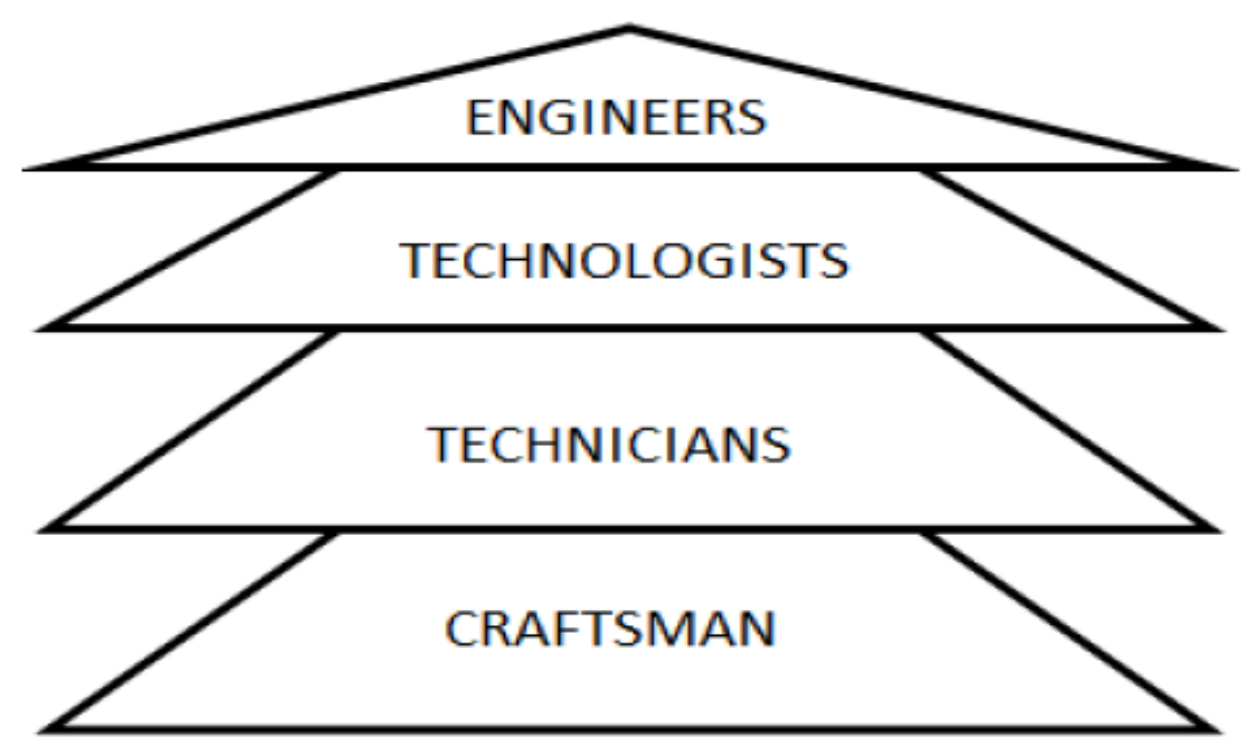

Figure 1. Engineering cadres in Nigeria (Bello, 2012)

\section{The Challenging Trend}

As far back as 1984, issues of vocational education has been in the front burner in Nigeria when the National Policy on Education (NPE) was introduced. By this policy, six years is expected to be spent in primary school, three years for junior secondary school, three years for senior secondary education, and four years in the university. By this arrangement, those who have academic qualifications stand a better chance of upward salary review than those who have vocational qualifications (Urevbu, 1984). Issues of promotion restriction is a big contributing factor to the neglect of vocational education has affected individuals would advise younger ones not to tread their own path if they want to have fulfilled careers.

In Nigeria today, the candidates that apply to study Engineering in Nigerian Universities are more than those applying to Polytechnics for Technical Education. Those who attend technical 
colleges have reduced to an alarming rate (Olajide, 2015). Government neglect of vocational and technical colleges play a damaging role in discouraging lots of youths from vocational and technical education and training (Seyi, 2014). Youths that are meant to be prepared for employment in recognized occupation are seeking white collar jobs due to factors such as; wrong government policies, embezzlement of fund meant for educational development, lack of motivation of teachers, inadequate funding, brain drain, poor staff training and welfare package, bribery and corruption to name a few (Okoye \& Arimonu, 2016). This pattern has equally affected the cadre-structure of Engineering. Most projects in the country are currently being handled by technicians and craftsmen from neighboring countries of West Africa due to the sorry state of outputs from vocational and technical institutions in Nigeria (Nworlu-Elechi, 2013).

In fact, what is observed now in Nigeria are cases of university graduates who due to lack of white collar jobs, informally enroll for apprenticeship/vocational training as a means of survival (Emunemu \& Kasali, 2014). Indirectly, the formal vocational training system incorporated into the secondary school system is fast becoming unpopular. This has brought about a new class of vocational practitioners who are highly educated but lack the patience to adequately master the requisite skills. Politicians are now coming out with various empowerment programmes seeking to train and pay selected few for durations ranging from one to two years as a means of alleviating poverty and unemployment rate reduction. This has made people see these government programmes as a means to get free money instead of dedicating their time and energy to acquiring skills, attention is simply on the stipend that would be paid at the end of the month (Aibieyi \& Dirisu, 2010; Taiwo \& Agwu, 2016).

\subsection{Other factors responsible for cadre-structure imbalance}

\subsubsection{Policy inflexibility}

The partial implementation of policy framework on the issue relating to dichotomy between University graduates and Polytechnic graduates by the Federal Government of Nigeria, discourages people from seeking technical education and training in the Polytechnics as shown in Figure 2. More people prefer to attend University to earn respect and reach the peak of their professional careers be it in government establishments (Federal or State owned) as well as private organizations (Garba, 2012). 


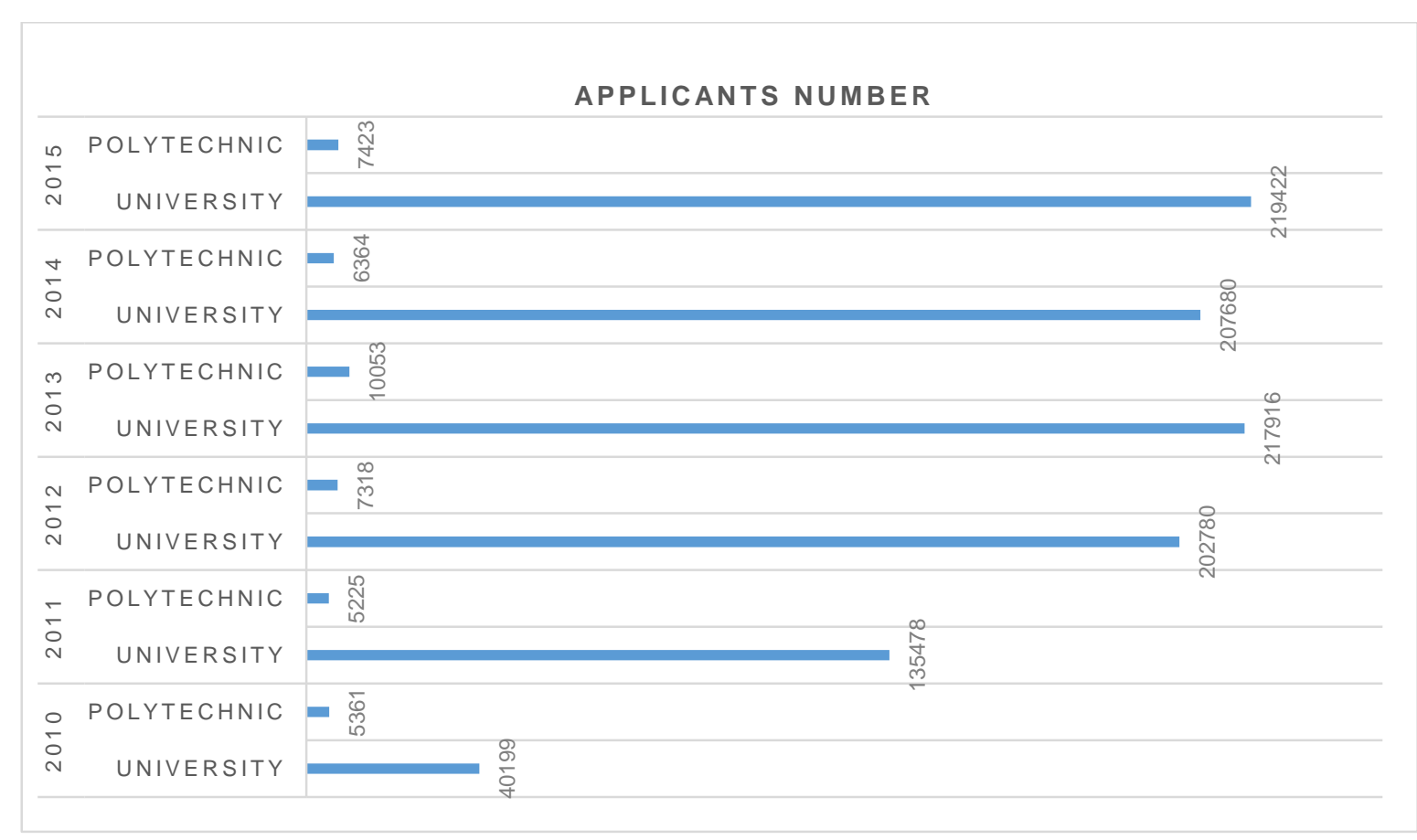

Figure 2. 2010-2015 application statistics

(Data source: JAMB 2010-2016 Application Statistics)

\subsubsection{Public misconception}

As it is commonly happening in Nigeria, anyone involved in Engineering projects, especially on sites, wearing helmet is assumed to be an engineer and therefore so addressed. These artisans answer the tag 'engineer' but with a silent agitation in their minds for self-esteem, respect, and acceptance similar to honorary traditional titles bearing in Nigeria (Lateju \& Oladosu, 2012; Uwalaka, 2014).

\subsection{Effect of cadre-structure imbalance}

There are several skills gap in the technical and engineering profession in Nigeria today. Due to rapid development of engineering sector of the economy, craftsmen, technicians and technologists are in short supply today (Okolocha, 2016). Artisans from neighboring countries and as far as Asia currently populate these cadres (Bilau et al., 2015). Few indigenous artisans, still available, are mostly aged and younger ones are busy pursuing qualifications to be registered as engineers with the expectation of a more dignified position with its attendant benefits (Asibeluo, 2015; Eneh, 2010). This has led to high unemployment rate amongst the engineering cadres. Infrastructural decay due to lack of prompt and adequate maintenance as a result of shortage of skilled workers. High cost of construction and infrastructural development. High pressure on government for fewer available jobs. Loss in terms of technology transfer as indigenous implementation personnel are few for meaningful technological transformation of Nigeria. 


\section{The Way Out}

As part of solutions to promote synergy among engineering cadres in Nigeria, the following are suggested:

- There should be special emoluments for teachers in technical and vocational institutions. This would serve as motivating factors for them to turn in their best for the students and the entire system.

- Continuous training of technical and vocational sector workers should be put in place in order for them to be relevant in the usage of modern technologies to improve their skills.

- Re-orientation of the general public regarding the relevance of technical and vocational skills as a way to boost Nigerian economy should be aggressively embarked upon by government at all levels - local government, state government, and federal government.

- Stakeholders of engineering bodies should be made to realize that no single body could exist alone without the supports of others. Synergy must be reinforced among these cadres. Workshops should be organized to address the need for cooperation in the engineering family in Nigeria for there to be a meaningful growth and development.

- Age and qualification barriers should be removed as part of entry requirements for technical and vocational education or training. This would encourage those seeking such trainings to freely enroll and improve their individuals' livelihood.

- All materials for technical and vocational training should be subsidized by government to encourage public private partnership.

- Private organizations should be encouraged to sponsor or participate in technical and vocational trainings as part of their corporate social responsibilities.

- Flexible promotional conditions to accommodate willing and qualified engineering personnels to move up the professional ladder should be put in place.

- Dispute resolution arm should be set up within engineering family in Nigeria.

- Mutual respect among cadres should be emphasized at all times.

\section{Conclusion}

No doubt, the constituents of engineering family in Nigeria is fast becoming heavy at the Engineer cadre which could lead to an imminent collapse of the cadre-structure with its dire consequences. All efforts must be on deck to salvage the situation immediately through concerted efforts of all stakeholders. For there to be a positive transformation and synergy amongst engineering cadres in Nigeria, due recognition and respect must be accorded every cadre as part of one big engineering family. The dichotomy that exist between holders of Higher National Diploma and Bachelor Degree holders must be abolished by the government of the Federal Republic of Nigeria with sincerity of purpose and Vocational and Technical Education should be given a place 
of pride and encouraged via scholarship amongst Nigerian youths to fill the rapidly depleting Craftsmen and Technical cadres of engineering profession in Nigeria.

\section{References}

Aibieyi, S., and Dirisu, E. (2010). National Poverty Eradication Programmes in Nigeria: Problems and Prospects. Lwati: A Journal of Contemporary Research, 7(2).

Akinsanya, O., and Omotayo, K. (2013). Falling Standard of Engineering Education in Nigeria Causes and Suggestions. International Journal of Advancements in Research \& Technology, 2(10), 93-96.

Asibeluo, I. (2015). The Effects of the Discrimination between Polytechnic Education and University Education on the Overall Technological Development of Nigeria. Industrial Engineering Letters, 5(2), 41-45.

Bello, S. (2012). Agricultural Engineering Principles \& Practice. Lagos: Dominion Publishing.

Bilau, A., Ajagbe, M., Kigbu, H., and Sholanke, A. (2015). Review of Shortage of Skilled Craftsmen in Small and Medium Construction Firms in Nigeria. Journal of Environment and Earth Science, 5(15), 98-110.

COREN. (2019). History of COREN. [Online]. Retrieved from: https://www.coren.gov.ng/aboutcoren/coren-history

Emunemu, B., and Kasali, O. (2014). Entrepreneurship Education and Graduates Unemployment in Oyo State, Nigeria. Africa Higher Education Review, 8(2), 17-25.

Eneh, O. (2010). Artisanship Disconnect: Declining Technical Apprenticeship and Artisan Service and the Implication for Nigeria's Future Development. Asian Journal of Industrial Engineering, 2, 37-51.

National Academies. (1999). Engineering Tasks for the New Century: Japanese and U.S. Perspectives. The National Academies Press (pp. 63-66).

Garba, S. (2012). The Impact of Colonialism on Nigeria Education and the Need for E-Learning Technique for Sustainable Development. Journal of Educational and Social Research, 2(7), 53-61.

JAMB. 2010-2016. Application Statistics. [Online]. Retrieved from: https://www.jamb.gov.ng/Statistics.aspx. Accessed on:22nd February, 2019.

Jayarajah, K., Saat, R., and Rauf, R. (2014). A Review of Science, Technology, Engineering \& Mathematics (STEM) Education Research from 1999-2013: A Malaysian Perspective. Eurasia Journal of Mathematics, Science \& Technology Education, 10(3), 155-163.

Jose, F., Vanessa, B., Francisco, V., and Alfonso, E. (2018). Efficient Entrepreneurial Culture: A Cross-Country Analysis of Developed Countries. International Entrepreneurship and Management Journal Springer, 14(1), 105-127.

Lateju, F., and Oladosu, O. (2012). Chieftaincy Titles in Yorubaland and their implications for growth and tolerance among Christians and Muslims. Lumina, 23(2), 1-17.

Meiksins, P., and Chris, S. (1993). Organizing Engineering Work a Comparative Analysis. Work and Occupations, 20(2), 123-146. 
Nworlu-Elechi, O. (2013). Technical and Vocational Education for National Transformation. Proceeding of $1^{\text {st }}$ ASUP Zone D National Conference pp. 21-37.

Olajide, S. (2015). Repositioning technical and vocational education toward eradicating unemployment in Nigeria. International Journal of Vocational and Technical Education, 7(6), 54-63.

Okolocha, C. (2016). The Role of Vocational and Technical Education (VTE) in Nigeria Democratic Dispensation. International Journal of Capacity Building in Education and Management, 2(4), $12-24$.

Okoye, R., and Arimonu, M. O. (2016). Technical and Vocational Education in Nigeria: Issues, Challenges and a Way Forward. Journal of Education and Practice, 7(3), 113-118.

Pleasants, J., and Olson, J. (2018). What is engineering? Elaborating the nature of engineering for K-12 education. Science Education, 103(1), 145-166.

Seyi, D. (2014). An Overview of Vocational and Technical Education in Nigeria under Secondary School Education System. International Journal of Technology Enhancements and Emerging Engineering Research, 2(6), 119-122.

Sheppard, S., Colby, A., Macatangay, K., and Sullivan, W. (2006). What is Engineering Practice? International Journal of Engineering Education, 22(3), 429-438.

Smith, C. (1990). Review: How Are Engineers Formed? Professionals, Nation and Class Politics. Work, Employment \& Society, 4(3), 451-470.

Taiwo, J., and Agwu, M. (2016). Problems and Prospects of Poverty Alleviation Programmes in Nigeria. International Journal of Business and Management Review, 4(6), 18-30.

UNESCO. (2010). Introduction in Engineering: Issues, Challenges and Opportunities for Development, produced in conjunction with the World Federation of Engineering Organizations (WFEO), the International Council of Academies of Engineering and Technological Sciences (CAETS) and the International Federation of Consulting Engineers (FIDIC). Paris: UNESCO Publishing.

UNESCO. (2012). Progress Report on the UNESCO Engineering Initiative (UEI). [Online]. Retrieved from: www.unesco.org/new/fileadmin/MULTIMEDIA/HQ/SC/pdf/UEI_report_2012.pdf

Urevbu, A. (1984). Vocational Education in Nigeria: A Preliminary Appraisal. International Journal of Educational Development, 4(3), 223-229.

Uwalaka, E. (2014). An Empirical Investigation of Attitudes and Beliefs toward the Resurgence of Traditional Titles and Honours among the Igbos. International Journal of Humanities and Social Science, 4(13), 22-29. 